\title{
Archetypical Component of the Law as a Basis to Differentiate Between the Western and the Eastern Legal Tradition
}

\author{
Olga Igorevna Miroshnichenko ${ }^{1}$ \\ ${ }^{1}$ Theory and history of state and law department, Law School, Far-Eastern Federal University, Vladivostok, \\ Russian Federation. \\ Correspondence: Olga Igorevna Miroshnichenko, Verhne-portovaya str., 66-40, Vladivostok, 690003, Russian \\ Federation. E-mail: olga-star.05@mail.ru
}

Received: August 18, 2014 Accepted: September 10, 2014 Online Published: November 15, 2014

doi:10.5539/res.v6n4p249

URL: http://dx.doi.org/10.5539/res.v6n4p249

\begin{abstract}
In the article the author explores the issue of the genesis of the law as a phenomenon of objective reality differentiating it according to the principle of belonging to the western and the eastern legal tradition. The methodology basis for this research is the analytical psychology conception of Carl Gustav Jung, who considered the collective unconscious to be the basis of the human culture, which has collective, universal and impersonal nature, identical for all individuals of a certain community. We suggest differentiating the western and the eastern legal traditions in accordance with the values of the archetype criterion, which is the dominating cultural idea, and which creates the basic influence on the legal regulation on the whole and, in particular, determines the role of the law in public life and estimation of the law as a value.
\end{abstract}

Keywords: psychoanalytical conception, legal tradition, cultural idea, archetype criterion, values, legal necessity, archetype

\section{Introduction}

The law is the most effective regulator of public relations in a civilized society. Being objective enough, it absolutely preserves the minimum of moral values as a basis, it's protected with the force of government, genetically or enforcedly, but necessarily respected by the majority of the society. However, its authority has evidently declined lately, even in the Western Europe, where the significance and priority of the law as the most effective regulator of public relations has never been argued. In our opinion, this was caused by excessive formalization of the law, loss of spiritual element and ties with the society from which it originated and by the interests of which it should be filled and gain its strength and depth. The loss of the effectiveness of the law is a move towards anarchy, to the loss of the most sensible regulating system by the humankind. We think that the way out of this crisis is to acknowledge the necessity and absolute priority of a cultural component of the law as a regulator of public relations. Understanding of the cultural stipulation of the law will force the researches to think about cultural sense of originally legal concepts, such as "norm", "law" in their original meaning, "state", "justice", etc. But this research is not aimed at the examination of these categories. We think that it's necessary to begin with the understanding of "polar" cultural evolution of the world. In his academic papers Alfred Toynbee paid a great attention to the differentiation of the world from the point of view of the peculiarities in development of its western and eastern parts. We also suppose that from the point of view of the dominating values, fixed in understanding of the world and the law, all legal world can be conditionally divided into so-called western and eastern legal culture traditions, each of them needs a separate and detailed research. And only after extracting what we propose to call a culturological basis of the law (the true meaning of its main concepts in the frame of western-eastern system of differentiation) we'll be able to predict and to increase the effectiveness of positive law as a regulator of public relations of a certain nation.

Thus, we think that a brief outline of the western and the eastern legal traditions is needed for any research in the area of common theory of law because the difference of the basic core of culture from the way the values are formed in "the legal West and East" determines the difference in the type of forming and understanding the law as a phenomenon. 


\section{Research Methodology}

It's important from the very beginning to define the main methodology. Thus, there are many concepts of typologization of culture, not each of them is suitable for the aims of this research. Before the beginning of the $20^{\text {th }}$ century there dominated in culturology a principle of universality which assumed a possibility of unification of all cultures. Being proved invalid, it was changed into the principle of uniqueness, which stood for the individuality of every certain local culture. We are not flat in both variants and suggest, basing on methodology pluralism and philosophy anthropology approach, to define the features common for the cultures of conditionally western and eastern areas. We do not dispute the fact that that each culture possesses a set of unique features and represents a special world, but it includes some features drawing it to the dominating social cultural variants (Polyakov \& Timoshina, 2005).

We suggest using, as a main conception, psychoanalytical conception by Carl Gustav Jung, who singled out in a culture the element of collective unconscious, which is of primary importance for our research.

\section{Discussion and Results}

So, according to Carl Jung's idea, the basis of human culture is a collective unconscious which has collective, universal and impersonal nature identical for all individuals of a certain community. Collective unconscious is a part of psyche which differs from personal unconscious by the fact that it is not due to the personal experience and it is not a personal gain (C. H. Jung). In this way Jung distinguished personal unconscious, which is based on the experience and was simply excluded from mind, from collective unconscious which is "due exclusively to the inheritance... and is basically represented with archetypes" (C. H. Jung). He introduced the concept of archetype-literally "pre-existent forms"- that in fact is the first, "elementary" motive. Thus, the main C. Jung's thesis reads as follows: besides a direct consciousness which is absolutely of personal nature (plus is stipulated by objective reality and personal experience) and collective unconscious, there exists one more psychic system of collective, universal and impersonal nature, common for all individuals of a certain community. This collective unconscious does not develop independently but is inherited and consists of archetypes which consequently become conscious and add a certain form to the content of psychic.

In fact, the German psychologist suggests recognizing one more, extra biological, form of instincts which is of great importance for culture. Biological instinctive behavior doesn't depend on the rational recognition of an individual. In the same way a cultural extra biological component, as a complex of inherited basic cultural patterns, makes an individual unconsciously follow the stereotypes fixed in his subconsciousness by distant ancestors. Certainly originally the formation of these archetypes (primary motives of behavior, cultural stereotypes) was stipulated by absolutely objective factors, like climate, geography, etc. But at present, even without all of these factors no longer actual due to the science achievements, making stereotypes on the level of collective unconscious remains even more significant as an extra rational motivator of behavior.

A similar conception but with an emphasis on the legal culture is at present being worked out by a well-known Russian scholar V. P. Malakhov. He determines the idea of spirituality, which, on one hand, is a constant, inert element, predisposed in any era. And, on the other hand, the peculiarities of every era will change the general understanding of spirituality. To understand the essence of legal conscience is necessary to define the dominants of spirituality, i.e. the factors having the most successive and profound influence on legal phenomena. V. P. Malakhov examines a legal culture as a phenomenon formed in a certain civilization on the basis of a combination of spiritual dominants unique for every civilization. He explores legal cultures of different civilizations and carries out a comparative analysis of the fundamental determining basics (Malakhov, 2002).

For this the Russian scholar singles out a category of collective legal conscience and determines its levels. The deepest one is the level on which ideas of the law, measures and order are analyzed. The next level is represented by systematic ideas of legal conscience which determine its structure. Then follows the level on which the most general concepts of legal conscience, forming the cognitive and estimating basics of legal conscience, are connected. The most "surface" layer is the legal terms, opinions and senses. On this level a direct contact wit reality is exercised, the mechanism of reflection of social reality operates, and the content of legal conscience is formed. V. Malakhov connects the origination and the operation of legal culture with the level of sense-forming ideas-"origin of a universal form, abstract and ontologically inherent for all legal cultures" (V. P. Malakhov). On this level an independence of legal culture as its primary element is formed. According to V. Malakhov, mutual influence of legal cultures begins with conception level-replacing for formal schematizing interaction with informal one, though he notes that qualitative difference in cultures "is exposed already on the level of system forming ideas" (Malakhov, 2002). Thus, on the conception level an external element of legal culture is formed. On this level occurs mutual influence of the logics of the system forming ideas, of legal values and 
discovery of regulatory and value defining background of legal life. It's easy enough to trace the analogy between V.P. Malakhov's conception level and C. Jung's collective unconscious.

Informal filling of the levels offered by the Russian scholar seems to be disputable, but the conception, which lets extract in the legal culture the levels correspondent to the psychological element of the general culture, is worth attention.

We think that the western and the eastern legal traditions should be differentiated according to this value archetype criterion which is the basic cultural dominant and which creates the main forming and purpose influence on all social regulators.

In our opinion, the essential difference between the western and the eastern legal cultures is demonstrated by the role of the law in public life and by understanding of the law as an absolute value.

Western legal tradition, named an individualistic one, considers law as synonym for individual freedom, which, in turn, is the most important independent value with a great role in the public life. Here we should remind of two main synonyms for the law-freedom and justice. In western understanding justice is formally legal category. Since the times of Aristotle and ancient Greece polis one of the most significant features of the law is using equal scale to non-equal individuals. That is the value of formal legal justice is determined by logically flawless application of the rule in evaluation of human actions. In the Early Modern period this thesis harmoniously is transferred into natural legal conception in which the law is some basic guarantee of an individual, i.e. the guarantee of freedom to do with one's own life, property, without any outside interference, in particular, form the government and the society. "An individual is born with the right to complete freedom and unlimited exercise of all the rights and privileges of the natural law... by nature he is empowered not only to protect his property, i.e. his life, freedom and possessions, from injury and abuse by other people but to judge and punish those who violate this law as well..." (Locke, 1960). The basis of Western European culture is so-called conception of private life, which means that an individual is free to do with his life independently in all spheres, without violating the freedoms of the others. Western justice is formally equal freedom of individuals responsible for themselves. To say figuratively, the society sets equal "rules of the game" for all its members but it is not responsible for those who cannot cope with the game. Thus, moral and legal values are strictly divided. American philosopher R. Nozick, the author of genetic theory of justice, says about moral obligations as follows (quite cynically for an average man): "from the moral point of view every individual is an owner of himself, that is, he can use his body and his forces- both intellectual and physical ones- as he likes. My ownership of myself is similar to the rights of ownership of a slave-owner to his slaves. The slave-owner has the right to dispose the life, force and abilities of his slave as he wishes, to give him for use by others individuals and no one can make him do it without his wish. In the same way no one has the right to make me act in the interests of others" (Nozick, 1974).

Thus, in the modern western world the law seems to be the most important and effective social regulator. It is always realized (or at least must be realized) in a formal legal form and it functions autonomously in relation to morality and religion. V. V. Bocharov says the following about western legal tradition," Judging by all this, the representatives of the West themselves sincerely continue to believe in the power of the laws which are able "automatically" to transform social realia in the necessary direction" (Bocharov, 2013).

The crisis of modern European civilization, represented by the fact that ethic and legal values lose their spiritual meaning and are used as a means to disguise selfish financial interests of people, led to a severe criticism of European legal ideals. V. N. Sinukov notes that "decay" of western capitalism, decline of culture and morals are the signs testifying the world problem of crisis in the western world, of its legal and social structure. Too huge values were accumulated by western culture, too significant is its existence for the stable world, not to consider this crisis as the world humankind problem. The western civilization needs an alternative..." (Sinyukov, 2010). As an alternative the author offers Russian culture, thinking that spiritually it is the closest to the western one. A well-known American theorist of law H. J. Berman says that "the West itself has already questioned the universality of its traditional thinking of the law...the law which seemed "natural" before proves to be only "the western". And many people say that it has become obsolete even for the West" (Bermann, 1998).

In Eastern, so-called collective cultures, the law is secondary in relation to religion and morality, and it has always been subjected to evaluation in order to establish its accordance with the pointed regulators. We've already noted that the law is only a part of the general cultural layer. In the archaic socium all social norms joined together were quite successful in exercising necessary regulation. In the western society, as it was said above, the law quickly transformed in a particular and quite effective social regulator based on the principles of realization of individual freedom and formal justice. So-called "common law", though it remained in the area of 
formal legal regulation but only as a secondary source of positive law. In the eastern society the process of law genesis followed a different direction.

One should remember the specifics of the eastern way of development in general, which was stipulated by the necessity to conduct large-scaled irrigation works and low development of tools. Hard climatic and geographical conditions and impossibility to live on one's own resulted in the fact that the social differentiation in the eastern community happened on the basis of political inequality. Economy relied on the state and public form of property and the private property, the cornerstone of the western freedom, didn't play any significant role. An eastern individual was much more limited and frightened with the nature than a western one. And this irrational fear towards the unknown became the basis for obedience but not the western conscious rational understanding of the necessity to co-exist. It's quite natural that the main source of social regulation is the codes of ethic and religious norms. These norms are of casuistic nature are enforced if necessary by other customs or by orders of a monarch who is taken for as a demigod.

While the basis of the western civilization is an independent individual, in the East an individual is important only as a part of a whole, not by himself. The West focuses on the mind, on the scientific and technical progress and on the value of a person as an individual. The East for a long time doesn't recognize the science as an independent activity and focuses on the spirituality.

It's not surprising that the basis of the eastern law is so-called "unwritten" or "not differentiated, common law", which, firstly, concentrates on such categories as "conscience", "shame", "sense of guilt", "remorse", etc., that are very far from positive legal concepts, and secondly, its effectiveness is to be stipulated by inner obligation and necessity. But these circumstances do not make it less legal. Here we can refer to the authority of a well-known French anthropologist N. Rouland, who speaking about the specifics of social regulation in the eastern countries says," Many traditional communities not only developed original conceptions in the sphere of the law but also often used what we consider to be our own invention, like law, court, punishment, contract..." (Rouland, 2000).

Characterizing the specifics of the legal culture of the eastern countries, V. V. Bocharov says that the power of "unwritten law" genetically pierces all eastern society. In fact, it is that very collective unconscious we've already mentioned. Together with his colleagues the scholar carried out several social experiments in which some definite legal procedures were conducted by both so-called "lawful" (formally legal, in accordance with the legislation in force) and "shadow" (in accordance with the common law). In the result he concluded that material and time expenditure and, what is more important, the result of the first variant compared with the second one is disappointing, to say it mildly. The author sums up that even in case of borrowing the western legal patterns, "under the external legal façade constructed in the European style there still will hide and actually work the legal practices traditional for these cultures" (Bocharov, 2013).

One more interesting evidence is the experience of B. Malinowsky, a well-known ethnographer, described in his book "Argonauts of the Western Pacific".

The main attention is paid to the phenomenon of Kula, which is a specific form of exchange between the tribes of Trobriand Islands, Papua New Guinea. Two commodities are transferred by the same route, soulava (red shell-disc necklaces) and mwali (white shell armbands), both travelling in opposite directions (B. Malinowsky says clockwise and counterclockwise directions). Every movement, the ceremony of exchange, etc. are strictly fixed. A limited number of people participate in the deal, and the commodity never remains in the hands of recipients - "once in the Kula, always in the Kula". The ethnographer says that any attempt to rationalize this exchange results in a complete crash of the whole procedure (Malinowsky, 2004).

The anthropologists invited to the island found out that "initiations" and "head hunting" were the "starting" events which provided the necessity of agricultural works and maintained the unity of families and community members. After the ban of "initiation festivity" and "head hunting" the mechanisms starting the whole system of cultural and normative ties disappeared. Sure it's possible to live without sowing rice, only thanks to the fruit harvest and fishing. But this area is notable for regular bad harvests and long periods of lack of fish. That's why it was the store of rice that guaranteed the survival of a tribe. Regular field works (not necessary if to judge by an immediate need) were to be supported with external means. This external symbolic support was "the head hunting". With the ban of this custom not only the ceremony of devoting the youths into adults was destroyed but more importantly a historical hierarchical structure of the community social organization.

Here we can make a very important conclusion: no legal affiliation can be found effective in case it is not stipulated by objective and subjective processes in a certain society and if it contradicts other elements of the social regulation of a definite social and cultural reality. Thus, what is effective for one nation can be disastrous 
for another one, as well as what some nation considers to be an archaism and lack of culture is a normal way of life for another.

So, we agree with N. Rouland's opinion that "in some cases the reception of a strange law can result in absence of legal culture (Rouland, p. 106). And taking into consideration the effectiveness of "non-differentiated law" which still exists nowadays, one can very reasonably claim that the usual archetype component of the traditional law, based in most cases on morality and religion, in the eastern communities is more effective regulator of public relations and, consequently, it is the real law.

\section{Conclusion}

Thus, having described the specifics of the western and the eastern legal traditions, we proved the idea that "worked out by centuries the values, norms and meanings which form the basics of civilization are the stabilizing factor to preserve the civilization heritage and to transfer it from generation to generation (V. S. Stepin, p. 76)." Where the main value is individualism and so-called "private life", like in the western society, there appears the need to establish clear legal rights and duties of an individual with the help of structured positive law which delimits one member of society from another by mutual strictly defined rights and duties. Where the main values are collective and the primary goal is harmony with nature and society, like in the eastern community, the most essential task is not the formal law but exposition of moral idea of a duty and its hidden sources. Thus, the basis of the legal culture of a certain society depends on native archetypes fixed in the subconscious of its members, as well as on the fact that the accordance with them is mostly the basis of legal necessity-moral and religious directive or a norm of positive law.

\section{References}

Belik, A. A. (Unknown). Culturology: Anthropological Theories of Cultures.

Bermann, H. J. (1998). The Western Legal Tradition. Moscow.

Bocharov, V. V. (2013). The unwritten law: Antropology of law (2nd ed.). Saint Petersburg. AIK publishing house.

Jung, C. H. (1995). The term of collective unconscious. In A. M. Putkevitch (Trans.), Analytical Psychology: The Past and the Present. Moscow, "Martis".

Locke, J. (1960). Treatise on Government. Selected Philosophical works. Moscow.

Malakhov, V. P. (2002). Philosophy of the Law. Moscow.

Malinowsky, B. (2004). Argonauts of the Western Pacific. Moscow, Rosman.

Nozick, R. (1974). Anarchy, Stateand Utopia. N.Y. Basicbook.

Polyakov, A. V., \& Timoshina, E. V. (2005). The general theory of law. Saint-Petersburg.

Rouland, N. (2000). Legal Anthropology. Moscow.

Rouland, N. (2000). Legal Anthropology. Moscow.

Sinyukov, V. N. (2010). Russian Legal System. Introduction into the General Theory.

Stepin, V. S. (2004). Philosophy and Civilization. A Man, Science and Civilization. Moscow.

\section{Copyrights}

Copyright for this article is retained by the authors, with first publication rights granted to the journal.

This is an open-access article distributed under the terms and conditions of the Creative Commons Attribution license (http://creativecommons.org/licenses/by/3.0/). 